\title{
Laparoscopic Approaches to Colorectal Liver Metastases
}

Sarkut $\mathbf{P}^{*}$ and Yilmazlar T

Uludag University School of Medicine

"Correspoding author: Sarkut P, Uludag University School of Medicine, Bursa, Turkey, Tel: 90-5324814960; E-mail: pinartasar@gmail.com

Received date: April 29, 2014; Accepted date: November 20, 2014; Published date: November 27, 2014

Copyright: $\odot$ 2014, Sarkut P, et al. This is an open-access article distributed under the terms of the Creative Commons Attribution License, which permits unrestricted use, distribution, and reproduction in any medium, provided the original author and source are credited.

\begin{abstract}
Colorectal cancer is the second most common cause of cancer-related death in Western countries. One third of these patients develop liver metastasis and $15-25 \%$ have liver metastasis at diagnosis. Resection and chemotherapy are gold standard for colorectal liver metastases. More effective chemotherapy regimens and advanced surgical techniques confer longer survival to patients with colorectal liver metastases. The role of laparoscopy in the diagnosis and treatment of these patients is increasing. With advances in technology and growing experience, laparoscopic approaches have come into prominence because of their superiority over open surgery, including decreased postoperative pain, lower morbidity, reduced time for return to ordinary daily life, and shorter hospitalization.
\end{abstract}

Keywords: Laparoscopy; Liver; Metastases; Colorectal cancer

\section{Introduction}

Colorectal cancer, the third most common malignancy in the USA [1], is the second most common cause of cancer-related death in Western countries [1,2]. One third of these patients develop liver metastasis and $15-25 \%$ have liver metastasis at diagnosis [3]. The gold standard treatment for liver metastasis is surgery and the 5-year survival rate after curative surgery is $33-58 \%$ [4-7]. In comparison, the average survival of untreated patients is $\sim 6$ months, and the main cause of death is liver failure [8]. The role of laparoscopy in the diagnosis and treatment of these patients is increasing. With advances in technology and growing experience, laparoscopic approaches have come into prominence because of their superiority over open surgery, including decreased postoperative pain, lower morbidity, reduced time for return to ordinary daily life, and shorter hospitalization. The disadvantages of laparoscopic surgery are controversial and include relapse at port sites, surgical margins, and oncological results.

\section{Diagnostic Laparoscopy}

Imaging techniques are used to assess the resectability of hepatic colorectal metastases. Computed tomography (CT), magnetic resonance imaging (MRI), and positron emission tomography (PET) can provide information about the size, number, vessel invasion, and extrahepatic expansion of lesions. Unfortunately, 9-25\% of the lesions are unresectable at laparotomy [9-12]. Diagnostic laparoscopy (DL) and laparoscopic ultrasound (LUS) can aid in the evaluation and staging of patients before resection. This prevents unnecessary major surgery with high morbidity and mortality, by showing undiagnosed occult metastasis that is not detected on imaging. Laparoscopy has some disadvantages, including limitations on its use due to scar tissue from previous surgery and difficulty detecting metastatic lymph nodes.

In 1999, Rahusen et al. investigated DL and LUS for evaluating colorectal liver metastases [11]. They found that the sensitivity of diagnostic ultrasound was $89 \%$ and that DL and LUS identified 18 of 47 patients as having unresectable lesions, showing that the combined use of DL and LUS could decrease unnecessary laparotomies and identify candidates for resection.

In 2007, Khan et al. published one of the largest series examining DL for colorectal liver metastases, performing laparoscopy in 210 of 284 patients [13]. The resectability rate was $87 \%$ and $39 \%$ of the unresectable patients were diagnosed using laparoscopy. This study showed that the routine use of DL increased the resectability ratio and decreased the rate of inoperable patients.

In 2010, Biondi et al. evaluated 62 of 65 cases completely by laparoscopy [14]. They also used the Clinical Risk Index. The falsenegative rate for DL/LUS was $21 \%$. They reported that laparoscopy was beneficial for detecting occult unresectable tumors.

Finally, Dunne et al. found that 12 patients identified as resectable by DL were unresectable after laparotomy [15]. They concluded that DL is not suitable for routine clinical practice, but convenient for controversial clinical cases (Table 1).

\begin{tabular}{|l|l|l|}
\hline & Year & Patients (n) \\
\hline Rahusen et al. [11] & 1999 & 50 \\
\hline Jarnagin et al. [10] & 2001 & 103 \\
\hline Gholghesaei et al. [16] & 2003 & 56 \\
\hline Metcalfe et al. [17] & 2003 & 24 \\
\hline Grobmyer et al. [18] & 2004 & 264 \\
\hline Koea et al. [19] & 2004 & 59 \\
\hline De Castro et al. [20] & 2004 & 43 \\
\hline Thaler et al. [21] & 2005 & 136 \\
\hline Mortensen et al. [22] & 2006 & 45 \\
\hline Mann et al. [2] & 2007 & 200 \\
\hline Khan et al. [13] & 2007 & 210 \\
\hline Pilkington et al. [23] & 2007 & 73 \\
\hline
\end{tabular}




\begin{tabular}{|l|l|l|}
\hline Biondi et al. [14] & 2010 & 65 \\
\hline Dunne et al. [15] & 2013 & 274 \\
\hline
\end{tabular}

Table 1: Studies using DL and LUS to evaluate patients with colorectal liver metastasis before resection.

\section{Laparoscopic Hepatic Artery Infusion Pump Chemotherapy}

Hepatic artery infusion pump chemotherapy (HAIPC) is used to treat unresectable hepatic colorectal cancer metastases. This device was first manufactured in 1980 [24]. It administers chemotherapeutic agents such as floxuridine and fluorouracil directly into the hepatic artery. Hepatic metastases receive $95 \%$ of their blood supply via the hepatic artery. Consequently, the local concentration of the chemotherapeutic agent is increased and there are fewer systemic side effects because $94-99 \%$ of the chemotherapeutic drugs are excreted via pre-systemic elimination [25].

Initially, HAIPC required a laparotomy. Then, in 1970, Watkins et al. performed this procedure via a laparoscopic approach, decreasing the morbidity related to a laparotomy [26]. The biggest problem with this technique is inappropriate perfusion resulting from accessory and replaced hepatic arteries. When inserting the pumps, ligation of variant arteries can prevent inappropriate reperfusion. Occasionally, the gastroduodenal artery can be used. In 1970, Felluci et al. reported three cases: two with synchronous liver metastasis and one with metachronous liver metastasis [27]. The patients with synchronous metastasis underwent laparoscopic colon resection and regional chemotherapy from the gastroduodenal artery. No complications were seen. The average procedure time was $70 \mathrm{~min}$. Urbach et al. reported a total of eight cases and demonstrated the need for controlled studies and an easily applicable method that enhances survival $[28,29]$.

In a study of patients with hepatic colorectal metastasis, Kemeny et al. reported that the 2-year and disease-free survival rates of patients with HAIPC were 86 and 90\%, respectively, versus 72 and $60 \%$ without it [25].

Cheng et al. performed laparoscopic radiofrequency ablation (LRFA) and laparoscopic HAIPC (LHAIPC) in patients with colorectal metastasis who had failed systemic chemotherapy [30]. After an average follow-up of $11.5 \pm 7.8$ months, the survival rates with LRFA, LHAIPC, and LRFA+LHAIPC were $70 \%, 50 \%$, and $67 \%$, respectively. Finally, Franklin et al. published a series of 27 cases, of which four had no colorectal metastasis [31]. After a median follow-up of 8.1 months, CT showed that 22 had tumor regression and the carcinoembryonic antigen (CEA) returned to normal in 18 within 1 month.

\section{Radiofrequency Ablation}

Radiofrequency ablation (RFA) uses electromagnetic energy to generate temperatures of $60-100^{\circ} \mathrm{C}$ in the target tissue, causing thermal injury [32]. It can be performed using percutaneous, open, and laparoscopic techniques. RFA is recommended for patients with fewer than three liver metastases $<3 \mathrm{~cm}$ in size or in patients in whom surgery is contraindicated. Most centers prefer patients with fewer than five lesions. The success rate of RFA limited in unresectable colorectal liver metastasis patients with tumor size $>5 \mathrm{~cm}$, multiple tumors, and inappropriately located tumors [33].
The incidence of major complications after percutaneous RFA in patients with colorectal liver metastasis is about 4-8\% [33-35]. The 3and 5-year survival rates after percutaneous RFA are $22-57 \%$ and $20-$ $48.5 \%$, respectively [36-45]. In most studies, hepatic resection was superior to RFA in patients with colorectal liver metastasis, except for Oshowo et al. [36] and Reuter et al. [42], who found no significant difference in survival (Table 2).

\begin{tabular}{|c|c|c|c|c|}
\hline \multirow[t]{2}{*}{ Author } & \multirow[t]{2}{*}{ Year } & \multirow[t]{2}{*}{ RFA/Resection(n) } & \multicolumn{2}{|c|}{$\begin{array}{l}\text { Survival (\%) } \\
\text { RFA/Resection }\end{array}$} \\
\hline & & & 3 year & 5 year \\
\hline $\begin{array}{ll}\begin{array}{l}\text { Oshowo } \\
\text { al. [36] }\end{array}\end{array}$ & 2003 & $25 / 20$ & $53 / 55$ & $36 / 42$ \\
\hline $\begin{array}{ll}\begin{array}{l}\text { Abdalla } \\
\text { al. [37] }\end{array} & \text { et }\end{array}$ & 2004 & $57 / 190$ & $37 / 73$ & $21 / 58$ \\
\hline Aloia [38] & 2006 & $30 / 150$ & $57 / 79$ & $27 / 71$ \\
\hline $\begin{array}{l}\text { White et al. } \\
\text { [45] }\end{array}$ & 2007 & $22 / 30$ & $84 / 82$ & $42 / 57$ \\
\hline $\begin{array}{l}\text { Gleisner et } \\
\text { al. [46] }\end{array}$ & 2008 & $11 / 192$ & $51 / 72$ & $28 / 51$ \\
\hline Lee [41] & 2008 & $37 / 116$ & $32 / 51$ & $49 / 66$ \\
\hline $\begin{array}{l}\text { Berber et al. } \\
\text { [47] }\end{array}$ & 2008 & $68 / 90$ & $35 / 70$ & $30 / 40$ \\
\hline $\begin{array}{l}\text { Hur et al. } \\
{[48]}\end{array}$ & 2009 & $25 / 42$ & $60 / 70$ & $26 / 50$ \\
\hline $\begin{array}{l}\text { Otto et al. } \\
{[49]}\end{array}$ & 2009 & $28 / 82$ & $67 / 60$ & $48 / 51$ \\
\hline $\begin{array}{l}\text { Reuter et al. } \\
\text { [42] }\end{array}$ & 2009 & $66 / 126$ & $42 / 55$ & $21 / 23$ \\
\hline $\begin{array}{l}\text { McKay et al. } \\
{[50]}\end{array}$ & 2009 & $43 / 58$ & $39 / 60$ & $23 / 43$ \\
\hline $\begin{array}{l}\text { Lee et al. } \\
{[51]}\end{array}$ & 2011 & $28 / 25$ & $36 / 68$ & $18 / 44$ \\
\hline $\begin{array}{l}\text { Kim et al. } \\
{[52]}\end{array}$ & 2011 & $177 / 278$ & $50 / 59$ & $36 / 45$ \\
\hline
\end{tabular}

Table 2: Studies comparing laparoscopic RFA and hepatic resection in patients with colorectal metastasis.

Kennedy et al. reported on their 10-year experience with LRFA in patients with colorectal liver metastasis [53]. For 130 cases, the 5-year survival rate was $28.8 \%$. In their series, 95 patients had primary tumors in the colon and 35 patients had primaries in the rectum. Ninety patients had metastasis to a single liver lobe and 40 patients had bilobar metastases. On multivariate analysis, lesion size and metastasis in two lobes were related to poor survival. The recurrence of local tumors was $9.2 \%$; of these, only $3.6 \%$ had tumors $\leq 3 \mathrm{~cm}$.

Aksoy et al. [54] studied LRFA in three groups of patients with colorectal liver metastasis: isolated local recurrence only $(n=31)$; local recurrence with new liver disease $(n=51)$; and local recurrence with systemic disease $(n=36)$. The average survival durations of the three groups were 39,26 , and 22 months, respectively, and the differences were significant. This study showed that recurrent liver metastasis 
Page 3 of 6

after RFA was frequently associated with new liver disease and systemic metastases.

Using LRFA in 234 patients with unresectable colorectal metastases, Siperstein et al. [55] found that the 5-year survival rate was $18.4 \%$. The number of metastases $<3$, size of largest tumor $<3 \mathrm{~cm}$, and preoperative $\mathrm{CEA}<200 \mathrm{ng} / \mathrm{dL}$ were predictive of survival.

Radiofrequency ablation can be performed on unresectable colorectal metastases, recurrent metastasis after hepatic resection, or small, solitary metastasis as an alternative to resection.

\section{Liver Resection}

More effective chemotherapy regimens and advanced surgical techniques confer longer survival to patients with colorectal liver metastases. Although resection is the gold standard, minimally invasive resection is superior to open surgery in terms of less blood loss, tissue trauma, and immunosuppressive effects. Previously only limited resections, such as laparoscopic metastasectomies and segmentectomies, could be performed. With advances in technology and growing experience, major hepatectomies can now be performed via a laparoscopic approach. The literature emphasizes the short- and long-term consequences of laparoscopic and open liver resections in these patients. In the literature, there are no differences between these two methods in terms of surgical site recurrence and disease-free survival. The major difficulties with laparoscopic surgery include the learning period and adhesions due to previous surgery.

Nguyen et al. is one of the largest studies of the long-term consequences in patients with colorectal liver metastasis [56]. They performed laparoscopic resections in 61 patients and hand-assisted laparoscopic liver resection in 44 patients. Four patients were switched to open hepatic resection because of bleeding. Laparoscopic major hepatic resection was performed $45 \%$ of the patients. The 1-, 3-, and 5year survival rates were 88,69 , and $50 \%$, respectively, and the diseasefree survival rates were 65,43 , and $43 \%$. Kazaryen et al. reported a 5 year survival rate of $51 \%$ and disease-free survival rate of $42 \%$ for 107 laparoscopic liver resections [57] (Table 3).

\begin{tabular}{|l|l|l|l|}
\hline Author & Year & Patients(n) & Survival \\
\hline ORourke et al. [58] & 2004 & 22 & $75 \%$ (2 year) \\
\hline Vibert et al. [59] & 2006 & 41 & $87 \%$ (3 year) \\
\hline Sasaki et al. [60] & 2009 & 39 & $64 \%$ (5 year) \\
\hline Robles et al. [61] & 2008 & 21 & $80 \%$ (3 year) \\
\hline Nguyen et al. [56] & 2009 & 109 & $50 \%$ (5 year) \\
\hline Kazaryan et al. [57] & 2010 & 107 & $51 \%$ (5 year) \\
\hline Huh et al. [62] & 2011 & 20 & $58.7 \%$ (3 year) \\
\hline Topal et al. [63] & 2012 & 20 & $48 \%$ (5 year) \\
\hline
\end{tabular}

Table 3: Laparoscopic liver resection and survival in patients with colorectal liver metastases.

A number of studies investigated the short- and long-term oncologic results of open surgery and laparoscopic liver surgery. In a series of 84 cases, Doughtie et al. performed eight laparoscopic major hepatectomies [64]. There was no difference in age, body mass index (BMI), size of the largest tumor, or transfusion between the methods, while the complication rate, length of hospital stay, and blood loss were significantly higher in the open surgery group. The average disease-free survival durations in the laparoscopic and open surgery groups were 14.4 and 13.2 months, respectively $(\mathrm{p}=0.34)$.

Inoue et al. retrospectively investigated the short-term results of laparoscopic hepatic resection; 23 of 47 colorectal hepatic metastases patients underwent laparoscopic hepatic resection, while the remainder underwent open resection [65]. Blood loss was significantly higher in the open surgery group. There were no differences in the pathologic surgical border, type of resection, postoperative complications, or duration of hospital stay. Postoperatively, the Creactive protein, leukocyte count and bilirubin were lower in the laparoscopic group.

There is no significant difference in the long-term survival between laparoscopic hepatic resection and open resection. Casting et al. evaluated the preoperative characteristics of 60 patients, including age, sex, primary tumor location, metastasis size, bilateral distribution of metastases, presence of extrahepatic disease, chemotherapy, and portal vein embolization before hepatectomy [66]. Both groups had a 60-day mortality rate of $1.7 \%$. The morbidity was $27 \%$ in the laparoscopy group and $28 \%$ in the open surgery group. The operating times and postoperative hospital stay were similar. The average follow-up duration was 30 months for the laparoscopic group and 33 months for the open surgery group. The respective 1-, 3-, and 5-year survival rates were $97 \%, 82 \%$, and $64 \%$ for the laparoscopic group and $97 \%, 70 \%$, and $56 \%$ for the open surgery group.

Welsh et al. published a series of 1152 cases, of which 266 were laparoscopic [67]. Blood loss and surgery duration were significantly lower in the laparoscopic group, while there were no significant differences in the duration of hospital stay, morbidity, or mortality. The 5- and 7-year survival rates in the laparoscopy group were 44 and $37 \%$, respectively, versus in 38 and $32 \%$ the open surgery group; the difference was significant ( $\mathrm{p}=0.005)$.

Topal et al. published a series of 274 cases, of whom 193 underwent open hepatic resections [68]. There were no differences between the groups in age, sex, preoperative systemic chemotherapy history, primary tumor location, or numbers of patients with multiple metastases, tumors $>5 \mathrm{~cm}$, or CEA $>200 \mathrm{ng} / \mathrm{dL}$. There was no significant difference in survival between the groups $(\mathrm{p}=0.63)$.

In a second study, Topal et al. examined 117 cases: 97 patients who underwent open hepatic resections and 20 with laparoscopic hepatic resections [63]. Of the 97 patients, 20 were matched with the laparoscopic group based on age, sex, location of hepatic metastasis, preoperative ablation therapy, simultaneous colorectal resection, and pre/postoperative chemotherapy. The survival rates of both groups were similar $(\mathrm{p}=0.87)$.

Canon et al. compared 35 laparoscopic resections and 140 open hepatic resections [69]. Age, BMI, size of the largest tumor, number of lesions, CEA level at the time of resection, positive lymph nodes, primary tumor size, and clinical risk scores were similar. The 1-, 3-, and 5-year disease-free survival rates in the laparoscopic groups were 79,37 , and $15 \%$, respectively, versus 78,35 , and $22 \%$ in the open surgery group. The respective 1-, 3-, and 5-year survival rates were 97, 63 , and $36 \%$ in the laparoscopic group and 95,60 , and $36 \%$ in the open surgery group. Both the disease-free and survival rates were similar (Table 4). 


\begin{tabular}{|l|l|l|l|l|l|}
\hline Author & Year & LR/OR(n) & Survival(\%) & Survival(\%) & P \\
\cline { 4 - 5 } & & LR & OR & \\
\hline $\begin{array}{l}\text { Casting et } \\
\text { al. [66] }\end{array}$ & 2009 & $60 / 60$ & $64 \%$ & $56 \%$ & $\mathrm{P}=0.32$ \\
\hline $\begin{array}{l}\text { Welsh et } \\
\text { al. [67] }\end{array}$ & 2010 & $266 / 886$ & $44 \%$ & $38 \%$ & $\mathrm{P}=0.005$ \\
\hline $\begin{array}{l}\text { Topal et al. } \\
\text { [63] }\end{array}$ & 2012 & $20 / 20$ & $48 \%$ & $45 \%$ & $\mathrm{P}=0.87$ \\
\hline $\begin{array}{l}\text { Topal et al. } \\
\text { [68] }\end{array}$ & 2012 & $81 / 193$ & $60 \%$ & $62 \%$ & $\mathrm{P}=0.62$ \\
\hline $\begin{array}{l}\text { Canon et } \\
\text { al. [69] }\end{array}$ & 2012 & $35 / 140$ & $36 \%$ & $42 \%$ & $\mathrm{P}=0.81$ \\
\hline
\end{tabular}

hepatic metastases from colorectal cancer. Fondation Française de Cancérologie Digestive. Br J Surg 82: 1397-1400.

9. Jarnagin WR, Fong Y, Ky A, Schwartz LH, Paty PB, et al. (1999) Liver resection for metastatic colorectal cancer: assessing the risk of occult irresectable disease. J Am Coll Surg 188: 33-42.

10. Jarnagin WR, Conlon K, Bodniewicz J, Dougherty E, DeMatteo RP, et al. (2001) A clinical scoring system predicts the yield of diagnostic laparoscopy in patients with potentially resectable hepatic colorectal metastases. Cancer 91: 1121-1128.

11. Rahusen FD, Cuesta MA, Borgstein PJ, Bleichrodt RP, Barkhof F, et al. (1999) Selection of patients for resection of colorectal metastases to the liver using diagnostic laparoscopy and laparoscopic ultrasonography. Ann Surg 230: 31-37.

12. Figueras J, Valls C, Rafecas A, Fabregat J, Ramos E, et al. (2001) Resection rate and effect of postoperative chemotherapy on survival after surgery for colorectal liver metastases. Br J Surg 88: 980-985.

Table 4: Survival after laparoscopic and open hepatic resection of colorectal liver metastases.

\section{Conclusion}

In summary, laparoscopy can be used to evaluate and treat colorectal liver metastasis. DL and LUS are quite sensitive determining the peritoneal involvement for the patients with resectable liver metastases of colorectal cancer. Moreover, RFA which mostly preferred treatment of patients with unresectabl liver metastases or used as a complementary of resection, helps (asists) to local control of tumor. Because of high ratio of local reccurrance, RFA should be preferred for selected patients. Conversely, even for selective patients, resection is superior to RFA at survival or disease-free survival. RFA exceeds resection just in terms of morbidity and hospitilization period. Presently, resection is being preferred at liver metastases of colorectal cancer. Laparoscopic surgery is safe and easy-usable, and has comparable oncological results with open surgery. Based on the studies reviewed, laparoscopic surgery has advantages over open surgery, although prospective randomized clinical trials are needed for a definitive conclusion on this matter.

\section{References}

1. Jemal A, Siegel R, Ward E, Hao Y, Xu J, et al. (2009) Cancer statistics, 2009. CA Cancer J Clin 59: 225-249.

2. Mann CD, Neal CP, Metcalfe MS, Pattenden CJ, Dennison AR, et al. (2007) Clinical Risk Score predicts yield of staging laparoscopy in patients with colorectal liver metastases. Br J Surg 94: 855-859.

3. Koshariya M, Jagad RB, Kawamoto J, Papastratis P, Kefalourous H, et al. (2007) An update and our experience with metastatic liver disease. Hepatogastroenterology 54: 2232-2239.

4. Fong Y, Fortner J, Sun RL, Brennan M, Blumgart MD, et al. (1999) Clinical score for predicting recurrence after hepatic resection for metastatic colorectal cancer: analysis of 1001 consecutive cases. Ann Surg 230: 309-321.

5. Choti MA, Sitzmann JV, Tiburi MF, Sumetchotimetha W, Rangsin R, et al. (2002) Trends in long-term survival following liver resection for hepatic colorectal metastases. Ann Surg 235: 759-766.

6. Pawlik TM, Scoggins CR, Zorzi D, Abdalla EK, Andres A, et al. (2005) Effect of surgical margin status on survival and site of recurrence after hepatic resection for colorectal metastases. Ann Surg 241: 715-722, discussion 722-4.

7. Scheele J, Stang R, Altendorf-Hofmann A, Paul M (1995) Resection of colorectal liver metastases. World J Surg 19: 59-71.

8. Rougier P, Milan C, Lazorthes F, Fourtanier G, Partensky C, et al. (1995) Prospective study of prognostic factors in patients with unresected

13. Khan AZ, Karanjia ND (2007) The impact of staging laparoscopy prior to hepatic resection for colorectal metastases. Eur J Surg Oncol 33: 1010-1013.

14. Biondi A, Tropea A, Basile F (2010) Clinical rescue evaluation in laparoscopic surgery for hepatic metastases by colorectal cancer. Surg Laparosc Endosc Percutan Tech 20: 69-72.

15. Dunne DF, Gaughran J, Jones RP, McWhirter D, Sutton PA, et al. (2013) Routine staging laparoscopy has no place in the management of colorectal liver metastases. Eur J Surg Oncol 39: 721-725.

16. Gholghesaei M, van Muiswinkel JM, Kuiper JW, Kazemier G, Tilanus HW, et al. (2003) Value of laparoscopy and laparoscopic ultrasonography in determining resectability of colorectal hepatic metastases. HPB (Oxford) 5: 100-104.

17. Metcalfe MS, Close JS, Iswariah H, Morrison C, Wemyss-Holden SA, et al. (2003) The value of laparoscopic staging for patients with colorectal metastases. Arch Surg 138: 770-772.

18. Grobmyer SR, Fong Y, D'Angelica M, Dematteo RP, Blumgart LH, et al. (2004) Diagnostic laparoscopy prior to planned hepatic resection for colorectal metastases. Arch Surg 139: 1326-1330.

19. Koea J, Rodgers M, Thompson P, Woodfield J, Holden A, et al. (2004) Laparoscopy in the management of colorectal cancer metastatic to the liver. ANZ J Surg 74: 1056-1059.

20. de Castro SM, Tilleman EH, Busch OR, van Delden OM, Laméris JS, et al. (2004) Diagnostic laparoscopy for primary and secondary liver malignancies: impact of improved imaging and changed criteria for resection. Ann Surg Oncol 11: 522-529.

21. Thaler K, Kanneganti S, Khajanchee Y, Wilson C, Swanstrom L, et al. (2005) The evolving role of staging laparoscopy in the treatment of colorectal hepatic metastasis. Arch Surg 140: 727-734.

22. Mortensen FV, Zogovic S, Nabipour M, Tønner Nielsen D, Pahle E, et al. (2006) Diagnostic laparoscopy and ultrasonography for colorectal liver metastases. Scand J Surg 95: 172-175.

23. Pilkington SA, Rees M, Peppercorn D, John TG (2007) Laparoscopic staging in selected patients with colorectal liver metastases as a prelude to liver resection. HPB (Oxford) 9: 58-63.

24. Kemeny N, Fata F (2001) Hepatic-arterial chemotherapy. Lancet Oncol 2: 418-428.

25. Kemeny NE, Ron IG (1999) Hepatic arterial chemotherapy in metastatic colorectal patients. Semin Oncol 26: 524-535.

26. Watkins E Jr, Khazei AM, Nahra KS (1970) Surgical basis for arterial infusion chemotherapy of disseminated carcinoma of the liver. Surg Gynecol Obstet 130: 581-605.

27. Feliciotti F, Paganini A, Guerrieri M, Chan R, Campagnacci R, et al. (1996) Laparoscopic intra-arterial catheter implantation for regional chemotherapy of liver metastasis. Surg Endosc 10: 449-452.

28. Urbach DR, Hansen PD (2000) Laparoscopic placement of a continuous hepatic artery infusion pump. below Semin Laparosc Surg 7: 140-147. 
$10.4172 / 2329-6771.1000125$

Page 5 of 6

29. Urbach DR, Herron DM, Khajanchee YS, Swanström LL, Hansen PD (2001) Laparoscopic hepatic artery infusion pump placement. Arch Surg 136: 700-704.

30. Cheng J, Hong D, Zhu G, Swanstrom LL, Hansen PD (2004) Laparoscopic placement of hepatic artery infusion pumps: technical considerations and early results. Ann Surg Oncol 11: 589-597.

31. Franklin $\mathrm{M}$, Trevino J, Hernandez-Oaknin $\mathrm{H}$, Fisher $\mathrm{T}$, Berghoff $\mathrm{K}$ (2006) Laparoscopic hepatic artery catheterization for regional chemotherapy: is this the best current option for liver metastatic disease? Surg Endosc 20: 554-558.

32. Darwazeh G, Prada Villaverde A, Kowdley GC, Cunningham SC (2013) Minimally invasive treatment of colorectal liver metastases. Minerva Chir 68: 27-39.

33. Van Tilborg AA, Meijerink MR, Sietses C, Van Waesberghe JH, Mackintosh MO, et al. (2011) Long-term results of radiofrequency ablation for unresectable colorectal liver metastases: a potentially curative intervention. Br J Radiol 84: 556-565.

34. Gillams AR, Lees WR (2004) Radio-frequency ablation of colorectal liver metastases in 167 patients. Eur Radiol 14: 2261-2267.

35. Machi J, Oishi AJ, Sumida K, Sakamoto K, Furumoto NL, et al. (2006) Long-term outcomeof radiofrequency ablation for unresectable liver metastases from colorectal cancer: evaluation of prognostic factors and effectiveness in first- and second-line management. Cancer J 12:318-26.

36. Oshowo A, Gillams A, Harrison E, Lees WR, Taylor I (2003) Comparison of resection and radiofrequency ablation for treatment of solitary colorectal liver metastases. Br J Surg 90: 1240-1243.

37. Abdalla EK, Vauthey JN, Ellis LM, Ellis V, Pollock R, et al. (2004) Recurrence and outcomes following hepatic resection, radiofrequency ablation, and com $\neg$ bined resection/ablation for colorectal liver metastases. Ann Surg 239: 818-825.

38. Aloia TA, Vauthey JN, Loyer EM, Ribero D, Pawlik TM, et al. (2006) Solitary colorectal liver metastasis: resection determines outcome. Arch Surg 141: 460-466.

39. Abitabile P, Hartl U, Lange J, Maurer CA (2007) Radiofrequency ablation permits an effective treatment for colorectal liver metastasis. Eur J Surg Oncol 33: 67-71.

40. Park IJ, Kim HC, Yu CS, Kim PN, Won HJ, et al. (2008) Radiofrequency ablation for metachronous liver metastasis from colorectal cancer after curative surgery. Ann Surg Oncol 15: 227-232.

41. Lee WS, Yun SH, Chun HK, Lee WY, Kim SJ, et al. (2008) Clinical outcomes of hepatic resection and radiofrequency ablation in patients with solitary colorectal liver metastasis. J Clin Gastroenterol 42: 945-949.

42. Reuter NP, Woodall CE, Scoggins CR, McMasters KM, Martin RC (2009) Radiofrequency ablation vs. resection for hepatic colorectal metas $\neg$ tasis: therapeutically equivalent? J Gastrointest Surg 13:486-491.

43. Gillams AR, Lees WR (2009) Five-year survival in 309 patients with colorectal liver metastases treated with radiofrequency ablation. Eur Radiol 19: 1206-1213.

44. Knudsen AR, Kannerup AS, Mortensen FV, Nielsen DT (2009) Radiofrequency ablation of colorectal liver metastases downstaged by chemotherapy. Acta Radiol 50: 716-721.

45. White RR, Avital, Sofocleous CT, Brown KT, Brody LA, et al. (2007) Rates and patterns of recurrence for percutaneous radiofrequency ablation and open wedge resection for solitary colorectal liver metastasis. J Gastrointest Surg 11: 256-263.

46. Gleisner AL, Choti MA, Assumpcao L, Nathan H, Schulick RD, et al. (2008) Colorectal liver metastases: recurrence and survival following hepatic resection, radiofrequency ablation, and combined resectionradiofrequency ablation. Arch Surg 143: 1204-1212.

47. Berber E, Tsinberg M, Tellioglu G, Simpfendorfer CH, Siperstein AE (2008) Resection versus laparoscopic radiofrequency thermal ablation of solitary colorectal liver metastasis. J Gastrointest Surg 12: 1967-1972.

48. Hur H, Ko YT, Min BS, Kim KS, Choi JS, et al. (2009) Comparative study of resection and radiofrequency ablation in the treatment of solitary colorectal liver metastases. Am J Surg 197: 728-736.
49. Otto G, Düber C, Hoppe-Lotichius M, König J, Heise M, et al. (2010) Radiofrequency ablation as first-line treatment in patients with early colorectal liver metastases amenable to surgery. Ann Surg 251: 796-803.

50. McKay A, Fradette K, Lipschitz J (2009) Long-term outcomes following hepatic resection and radiofrequency ablation of colorectal liver metastases. HPB Surg 2009: 346863.

51. Lee KH, Kim HO, Yoo CH, Son BH, Park YL, et al. (2012) Comparison of radiofrequency ablation and resection for hepatic metastasis from colorectal cancer. Korean J Gastroenterol 59: 218-223.

52. Kim KH, Yoon YS, Yu CS, Kim TW, Kim HJ, et al. (2011) Comparative analysis of radiofrequency ablation and surgical resection for colorectal liver metastases. J Korean Surg Soc 81: 25-34.

53. Kennedy TJ, Cassera MA, Khajanchee YS, Diwan TS, Hammill CW, et al. (2013) Laparoscopic radiofrequency ablation for the management of colorectal liver metastases: 10-year experience. J Surg Oncol 107: 324-328.

54. Aksoy E, Aliyev S, Taskin HE, Birsen O, Mitchell J, et al. (2013) Clinical scenarios associated with local recurrence after laparoscopic radiofrequency thermal ablation of colorectal liver metastases. Surgery 154: 748-752.

55. Siperstein AE, Berber E, Ballem N, Parikh RT (2007) Survival after radiofrequency ablation of colorectal liver metastases: 10-year experience. Ann Surg 246: 559-565.

56. Nguyen KT, Laurent A, Dagher I, Geller DA, Steel J, et al. (2009) Minimally invasive liver resection for metastatic colorectal cancer: a multi-institutional, international report of safety, feasibility, and early outcomes. Ann Surg 250: 842-848.

57. Kazaryan AM, Pavlik Marangos I, Rosseland AR, Røsok BI, Mala T, et al. (2010) Laparoscopic liver resection for malignant and benign lesions: ten-year Norwegian single-center experience. Arch Surg 145: 34-40.

58. O'Rourke N, Shaw I, Nathanson L, Martin I, Fielding G (2004) Laparoscopic resection of hepatic colorectal metastases. HPB (Oxford) 6: 230-235.

59. Vibert E, Perniceni T, Levard H, Denet C, Shahri NK, et al. (2006) Laparoscopic liver resection. Br J Surg 93: 67-72.

60. Sasaki A, Nitta H, Otsuka K, Takahara T, Nishizuka S, et al. (2009) Tenyear experience of totally laparoscopic liver resection in a single institution. Br J Surg 96: 274-279.

61. Robles R, Marín C, Abellán B, López A, Pastor P, et al. (2008) A new approach to hand-assisted laparoscopic liver surgery. Surg Endosc 22: 2357-2364.

62. Huh JW, Koh YS, Kim HR, Cho CK, Kim YJ (2011) Comparison of laparoscopic and open colorectal resections for patients undergoing simultaneous R0 resection for liver metastases. Surg Endosc 25: 193-198.

63. Topal H, Tiek J, Aerts R, Topal B (2012) Outcome of laparoscopic major liver resection for colorectal metastases. Surg Endosc 26: 2451-2455.

64. Doughtie CA, Egger ME, Cannon RM, Martin RC, McMasters KM, et al. (2013) Laparoscopic hepatectomy is a safe and effective approach for resecting large colorectal liver metastases. Am Surg 79: 566-571.

65. Inoue $\mathrm{Y}$, Hayashi M, Tanaka R, Komeda K, Hirokawa F, et al. (2013) Short-term results of laparoscopic versus open liver resection for liver metastasis from colorectal cancer: acomparative study. Am Surg 79: 495-501.

66. Castaing D, Vibert E, Ricca L, Azoulay D, Adam R, et al. (2009) Oncologic results of laparoscopic versus open hepatectomy for colorectal liver metastases in two specialized centers. Ann Surg 250: 849-855.

67. Welsh FK, Tekkis PP, John TG, Rees M (2010) Open liver resection for colorectal metastases: better short- and long-term outcomes in patients potentially suitable for laparoscopic liver resection. HPB (Oxford) 12: 188-194.

68. Topal B, Tiek J, Fieuws S, Aerts R, Van Cutsem E, et al. (2012) Minimally invasive liver surgery for metastases from colorectal cancer: oncologic outcome and prognostic factors. Surg Endosc 26: 2288-2298. 
Citation: Sarkut P, Yilmazlar T (2014) Laparoscopic Approaches to Colorectal Liver Metastases. J Integr Oncol 3: 125. doi: 10.4172/2329-6771.1000125

Page 6 of 6

69. Cannon RM, Scoggins CR, Callender GG, McMasters KM, Martin RC 2nd (2012) Laparoscopic versus open resection of hepatic colorectal metastases. Surgery 152: 567-573. 